原著

$$
\begin{aligned}
& \text { 胆道癌の進展 } \\
& \text { 一手術例及び剖検例の検討一 } \\
& \text { 川崎市立川崎病院外科 } \\
& \text { 斉 藤 敏 明 横 山 睝 新 井 健 之 } \\
& \text { 山田良 成 }
\end{aligned}
$$

\title{
A STUDY OF CANCEROUS INVOLVEMENT IN THE SURGICAL AND AUTOPTIC CASES OF BILIARY TRACT CARCINOMA
}

\author{
Toshiaki SAITO, Isao YOKOYAMA, Takeyuki ARAI \\ and Yoshinari YAMADA
}

Department of Surgery, Kawasaki Municipal Kawasaki Hospital

切除22例, 剖検46例の胆道癌について検討を行った.

切除例については胆管癌 7 例, 胆爱癌 12 例, 乳頭部癌 3 例で, 胆管癌では非治瘾切除 となったのは 3 例で，癌の進展が Hinf, Vによるむのであった。リンバ節転移は比較的 少なく $\mathrm{n}_{2}$ は 1 例であった。 6 年以上生存は治痔切除の 2 例のみであった。胆要癌では治 瘾切除 9 例, 非治瘾切除は 3 例で，癌の進展はHinf, 術中診断の誤りなどであり，また リンパ節転移では $\mathrm{n}_{3}$ が 3 例に認められた。 3 年生存は 1 例, 6 年生存の 1 例は早期癌で あった，乳頭部癌については 3 例とも治瘾切除であったが 2 例にPanc が認められ再発 死亡した。

剖検例について癌の進展をみると，胆管癌17例では Hinf (50\%)，H $(50 \%)$, 肺転移 (15\%)，リンパ節転移は肝門，荤周囲に15\%程度に認められた。胆变癌25例においては Hinf $(89 \%), \mathrm{H}(26 \%), \mathrm{P}(52 \%)$ ，肺転移（36\%)，リソパ節転移は肝門，膵周囲に多く， 旁大動脈にも36\%に認められた。乳頭部癌 3 例については 1 例を除き, 肝, 肺, 脺周囲 リンパ節転移が認められた。

組織像との関連をみると，胆管癌では高分化腺癌76\%，中・低分化腺癌24\%で，肝転 移は高分化型の $30 \%$ に対し，中・低分化型では100\%に認められた．胆垔癌では高分化腺 癌 $52 \%$ ，中・低分化腺癌40\%で胆管癌より低分化の傾向にある，中・低分化型では肝転 移50\%，肺転移60\%，旁大動脈リンパ節転移70\%に認められ，高分化型より多い。

以上の所見から胆管癌に括いては遠隔転移，リンハ節転移は比較的少なく，抬大手術 により局所を完全に切除出来ればその予後は比較的期待出来るすのと考えられる。これ に反し胆癌においては癌の進展は高度で, 早期発見, 早期手術の必要性が痛感される.

索引用語：胆道癌, 胆管癌, 胆咅癌, 乳頭部癌, 癌進展

\section{緒}

癌に対する治療が長足の進歩をとげたとは云え，胆 道癌における手術成績は極めて不良である，その理由 は早期発見，早期診断の困難性もさることながら，癌 病巣が肝, 胆, 荤, 肝動脈および門脈などに接し、癌
進展によっては合併切除を行っても尚根治性に久ける 場合もあり，また腹膜播種或は遠隔転移により切除を 断念せざるを得ない場合す展々みられるからである。 われわれは過去 12 年間に経験した胆道癌の進展を手 術例および剖検例から検討を行い, 今後の胆道癌手術 
においていささかでも参考になればと思い報告する次 第である。

\section{対象および方法}

昭和 45 年 10 月より昭和 57 年 9 月までの 12 年間に，わ れわれが経験した胆道癌症例は68例で，内訳は胆管癌 29例, 胆慗癌35例, 乳頭部癌 4 例である(表 1 )。性別 では男性32例，女性36例で，疾患別にみると胆管癌で は男性に多いが，胆表癌では女性に多い，年龄は26歳 より83歳むでで平均64歳であった，疾患別では胆管癌 では60歳代に多いが，胆基癌では70歳代に多い。

手術例は55例で，その5ち切除例は22例(切除率 $32 \%$ ，非切除例は33例であった。非手術例は13例であ る(表 2 ). 疾患別にみると，胆管癌では切除 7 例（切 除率24\%)であるが，胆衰癌では切除12例(切除率34\%) であり，乳頭部癌では 4 例中 3 例が切除されている.

剖検し得たのは46例で，胆管癌17例，胆峦癌25例， 乳頭部癌 4 例である。この5ち術後例が胆管癌におい ては10例，胆高癌においては20例，乳頭部癌は 4 例之 る手術例である。

肉眼的には外科胆道癌取扱い規約に則り検討し，組 織学的には HE染色を行い，組織像は主たる所見を 以ってした。

\section{成 績}

I. 手術例における癌進展

1) 胆管癌の臨床

胆管癌の占拠部位を胆道癌取扱い規約によりみると

\section{表 1 胆道演症例}

\begin{tabular}{|c|c|c|c|}
\hline & \multicolumn{3}{|c|}{$S 45$ 年 10 月～S S7年 9 月 } \\
\hline & 男 泩 & 女 性 & 計 \\
\hline 胆 管 癌 & 20例 & 9例 & 29例 \\
\hline 胆 軎 癌 & 10 & 25 & 35 \\
\hline 乳頭部痽 & 2 & 2 & 4 \\
\hline 計 & 32 & 36 & 68 \\
\hline
\end{tabular}

表 2 手 術

\begin{tabular}{|c|c|c|c|c|c|c|c|}
\hline & & 切 & 除 & & \multirow{2}{*}{ 非切除 } & \multirow{2}{*}{ 非手術 } & \multirow{2}{*}{ 計 } \\
\hline & 治 & 恣 & \multicolumn{2}{|c|}{ 非治策 } & & & \\
\hline 胆 管 癌 & 4例 & $14 \%$ & 3例 & $10 \%$ & 15例 & 7例 & 29例 \\
\hline 胆 裔 癌 & 9 & 26 & 3 & 8 & 17 & 6 & 35 \\
\hline 乳頭部 癌 & 3 & 75 & & & 1 & & 4 \\
\hline 計 & 16 & 23 & 6 & 9 & 33 & 13 & 68 \\
\hline
\end{tabular}

（図 1)，切除例 7 例では $B_{s-m}$ かi 4 例， $B_{1} 2$ 例， $B_{m 1} 1$ 例で，進展は $\mathrm{G}_{3}, \mathrm{~S}_{3}$ (胃)， $\mathrm{D}_{3}, \mathrm{~V}_{3}$ などであり， $\mathrm{n}_{1} 2$ 例, $\mathrm{n}_{2} 1$ 例で, Stage I 1 例, Stage II 2 例, Stage III 2 例, Stage IV 3 例であった。 術式は䐙頭十二指 腸切除 4 例, 脞頭十二指腸切除兼肝門部胆管切除 1 例, 胆复・胆管切除 1 例，胆数・胆管切除兼肝部分切除 1 例である.この5ち 4 例は治㾏切除， 3 例は非治瘏切 除である（表 3 ）。非治㦄切除となった理由は Hinf, V 因子のためであった。現在生存は 2 例で Stage I およ び Stage II の症例で, 夫々術後 7 年たよび 8 年の現在 元気である。

胆管癌非切除例は15例で，癌占拠部位は $\mathrm{B}_{\mathrm{sm}} 4$ 例， $B_{m 1} 4$ 例, $B_{s-1} 1$ 例, $B_{s-r 1} 3$ 例, $B_{s-r} 1$ 例, $B_{h} 1$ 例, $\mathrm{B}_{1} 1$ 例である. 癌進展は $\mathrm{G}_{3}, \mathrm{Hinf}_{3}, \mathrm{D}_{3}, \mathrm{H}_{3}, \mathrm{P}_{3}$, Panc 2、 $\mathrm{N}_{2-3}$ なとであり, 術式は単開腹 5 例, 胆管空

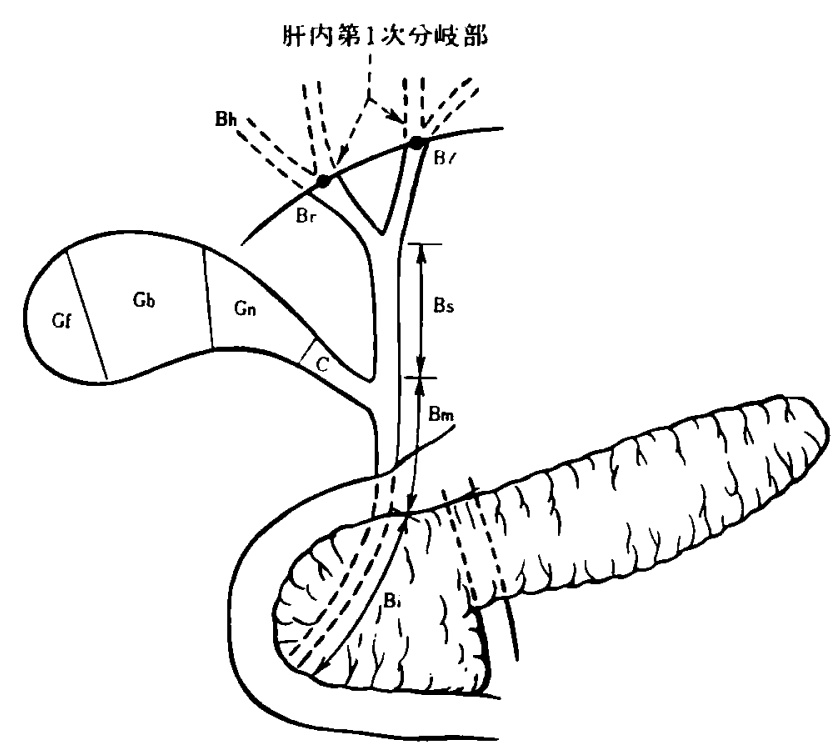

图 1 肝外胆道系の区分

表 3 胆管瘦切除例

\begin{tabular}{|c|c|c|c|c|c|c|}
\hline & 年齢 & 占居部 & 式 & 根治度 & 凓進展 & 転 螮 \\
\hline 1 & $\begin{array}{c}58 \\
\text { 今ิ }\end{array}$ & $\mathrm{Bi}$ & $\begin{array}{l}\text { 䏽頭十二指腸切 } \\
\text { 除 }\end{array}$ & $\mathrm{AC}$ & $\mathrm{n}_{0}$ & ( 8 告 \\
\hline 2 & \begin{tabular}{c}
67 \\
\multirow{\delta}{0}{}
\end{tabular} & " & " & " & $\mathrm{n}_{1}$ & （ $\begin{array}{l}\text { 生 } \\
7 \text { 年) }\end{array}$ \\
\hline 3 & $\begin{array}{l}72 \\
\hat{\jmath}\end{array}$ & $B_{s-m}$ & 胆重・胆管切除 & " & $\mathrm{n}_{0}, \mathrm{G}_{2}$ & 死 \\
\hline 4 & $\begin{array}{l}65 \\
\text { + }\end{array}$ & " & $\begin{array}{l}\text { 盟衰・盟管切除, } \\
\text { 部分切除 }\end{array}$ & RN & $\begin{array}{l}\mathrm{n}_{0}, \operatorname{Hinf}_{3}, \\
\mathrm{G}_{3}\end{array}$ & 死 \\
\hline 5 & $\begin{array}{l}50 \\
\hat{\delta}\end{array}$ & " & $\begin{array}{l}\text { 䐙頭十二指腸切 } \\
\text { 除, 肝門切除 }\end{array}$ & $\mathrm{AC}$ & $n_{0}, S_{2}, G_{2}$ & 死 \\
\hline 6 & $\begin{array}{c}52 \\
\text { 今人 }\end{array}$ & " & 腧頭十二指渴切 & AN & $\mathfrak{n}_{0}, \operatorname{Hinf}_{2}$ & 死 \\
\hline 7 & $\begin{array}{c}66 \\
\delta\end{array}$ & $B_{m !}$ & " & " & $n_{1}, S_{2}, V_{2}$ & 死 \\
\hline
\end{tabular}


腸吻合 4 例, 胆管内挿管 2 例, 胆基外瘦 1 例, Soupault 手術 1 例, 胃空腸吻合 1 例, 胆重空腸吻合 1 例であっ た(表 4 ). 非切除の理由は Hinf, H, P 因子などであっ た。生存期間は最長 2 年, 最短 1 カ月, 平均 7 カ月で あった。

胆管癌非手術例は 7 例で，諸検查による推定癌占拠 部位は $B_{1} 2$ 例, $B_{h} 1$ 例, $B_{r 1} 1$ 例, $B_{s} 1$ 例, $B_{s m} 1$ 例， $B_{s-1} 1$ 例と考光られた。癌の進展は $\mathrm{H}, \mathrm{Hinf}, \mathrm{G}$ 因子などが推察された。非手術の理由は H, Hinf, 高 齢，吐血死亡などであった。入院より死亡までの期間 は 2 週上り 5 カ月であった。

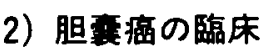

胆震癌の占拠部位をみると, 診断の遅れのため殆ん とが 2 区域以上に亘って招り，特に手術例においても 胆要全体を占めるものが14例と約 $48 \%$ を占めている （表 5 ）. 切除例は 12 例で切除率は $34 \%$ で，治㦄切除 9 例, 非治瘾切除 3 例であった。切除例における癌進展 は $\mathrm{Hinf}_{1}, \mathrm{~S}_{3}$ (横行結腸)， $\mathrm{n}_{2}$ ，などがあるが合併切除に 上り治虑切除し得る. Stage 別では I 3 例, II 1 例, III 7 例, IV 1 例である. 非治瘾切除となった理由は 術前・術中診断を誤り胆石症として処置してしまい。

\section{表 4 手術時所見}

-55 例-

\begin{tabular}{|c|c|c|c|c|c|c|c|c|c|c|c|c|}
\hline & & & $\mathrm{N}$ & $\mathrm{S}$ & Hinf & $P$ & $\mathrm{H}$ & G & Panc & D & V & B \\
\hline \multirow{2}{*}{$\begin{array}{l}\text { 盟 } \\
\text { 䈍 }\end{array}$} & 切 除 & 7例 & 3 & 5 & 2 & & & & & 1 & 1 & \\
\hline & 非切除 & 15 & 15 & 15 & 11 & 3 & 1 & 5 & 2 & 2 & & \\
\hline \multirow{2}{*}{$\begin{array}{l}\text { 盟 } \\
\text { 戥 }\end{array}$} & 切 除 & 12 & 5 & 8 & 3 & & & & & & & 3 \\
\hline & 非妡除 & 17 & 17 & 17 & 15 & 8 & 3 & & & 2 & & 9 \\
\hline \multirow{2}{*}{ 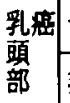 } & 切 除 & 3 & & & & & & & 2 & 2 & & \\
\hline & 非切除 & 1 & & 1 & & & & & & & & 1 \\
\hline
\end{tabular}

表 5 胆重癌の占居部位と進展 (手術例)

\begin{tabular}{l|r|l||r|l}
\hline & \multicolumn{2}{|c||}{ 切除 例 } & \multicolumn{2}{|c}{ 非切 除例 } \\
\hline 占居部位 & 例数 & \multicolumn{1}{c|}{ 進 展 } & 例数 & \multicolumn{1}{|c}{ 進 展 } \\
\hline $\mathrm{CBm}$ & 1 & $\mathrm{~S}_{2}$ & 1 & $\mathrm{P}_{2}$ \\
$\mathrm{Gn}$ & 2 & $\mathrm{~S}_{1}, \mathrm{~S}_{2}$ & 3 & $\mathrm{H}_{3}, \mathrm{Hinf}_{2}, \mathrm{P}_{2}, \mathrm{P}_{3}$ \\
$\mathrm{~Gb}$ & 3 & $\mathrm{n}_{1}, \mathrm{~S}_{2}, \mathrm{Hinf}_{1}$ & 1 & $\mathrm{P}_{3}$ \\
$\mathrm{Gf}$ & 1 & & & \\
$\mathrm{Gbf}$ & 2 & $\mathrm{~S}_{3}, \mathrm{Hinf}_{1}$ & 1 & $\mathrm{Hinf}_{3}$ \\
$\mathrm{G}_{\mathrm{n}-\mathrm{f}}$ & 3 & $\mathrm{n}_{2}, \mathrm{~S}_{1}, \mathrm{~S}_{2}$ & 11 & $\mathrm{H}_{2}, \mathrm{Hinf}_{3}, \mathrm{P}_{2}, \mathrm{P}_{3}$, \\
\hline 計 & 12 & & & $\mathrm{~N}_{3}, \mathrm{~N}_{4}$ \\
\hline
\end{tabular}

再手術し得なかった為である。術後成績は多くは 2 年 以内にて死亡したが，現在生存は術後 4 年生存 1 例打 よび 7 年生存 1 例で, 後者は胆石症として単純胆摘を 行った早期胆䗅癌であった。

非切除例は17例で，殆んどの症例において癌は胆衰 全体を占め, また殆んど $\mathrm{Hinf}_{3} て ゙, H$ H 3 例に, Pは 8 例， Bは11例，Dも2例に認められた。リンパ節転移 も殆んど $\mathrm{N}_{2}$ ないし $\mathrm{N}_{3}$ であった。非切除となった理由 は $\mathrm{Hinf}_{3}$ が 7 例で最も多く, 次いで $\mathrm{P}_{1 \sim 3}$ が 5 例, $\mathrm{H}_{2-3}$ が 3 例などであった。

術後生存はすべて 9 カ月以内に死亡し, 平均生存は 4 カ月であった。

非手術例は 6 例で, 癌進展は $\mathrm{Hinf}_{3} 3$ 例, $\mathrm{H}_{2} 1$ 例, $\mathrm{P}_{3} 1$ 例, 肺転移 2 例などであり, 非手術となった理由 もこのためであった，入院より死亡までの期間は 1 カ 月より11カ月で, 平均 3.5 月であった。

\section{3）乳頭部癌の咟床}

乳頭部癌は 4 例で, 切除 3 例, 非切除 1 例である. 切除例は Stage I, II, III 各 1 例づつで Pancによって Stage が進行した、リンパ節転移は認められなかった。 非切除の 1 例は膵及び総胆管への浸潤が著明であっ た. 予後は Stage Iの 1 例は術後 1 年10カ月にて他病 死したが, 剖検により癌再発は認められなかった。 Stage II 及び III の例は術後 9 カ月及び 1 年にて再発 死亡した。

\section{II. 剖検例にわける癌進展}

剖検し得た44例の内訳は胆管癌17例, 胆襄癌25例, 乳頭部癌 4 例である(表 6 )。ここれには切除後の症例か 11例（胆管癌 4 例, 胆衰癌 4 例, 乳頭部癌 3 例) が含 まれている。

\section{1）胆管癌剖検例}

胆管癌剖検例は17例で, 癌進展は肝浸潤が 9 例 (53\%), 胆衰浸潤 4 例(24\%), 肝門部浸潤 5 例(30\%), 十二指腸浸潤 3 例 (18\%), 苹浸潤 2 例 (12\%) などで, 迋隔転移は肝が最も多く8 例 (47\%), 肺 2 例 (12\%), その他腎，副腎，骨が1例つつつであった。腹膜播種は 2 例に認められた。リンバ節転移は肝門部及び苹周囲 に 4 例づつ, 腸間膜に 3 例認められたが旁大動脈には 認められなかった。

胆管癌切除後再発の剖検例をみると, 治瘾切除と考 えられた 2 例においても肝門部再発或は肝門部リンパ 節転移が認められ，1例には肝転移も認められた。非 治㕠切除例においても当然のことながら局所再発が $100 \%$ に認められ, 肝転移や癌性腹膜炎も認められた。 


\section{表 6 剖検所見}

-46 例一

\begin{tabular}{|c|c|c|c|c|c|c|c|c|c|c|c|c|c|c|c|c|c|c|c|c|c|}
\hline & \multicolumn{8}{|c|}{ 浸 } & \multicolumn{7}{|c|}{ 転 } & \multicolumn{4}{|c|}{ リンハ・節転移 } \\
\hline & & & $\begin{array}{l}\text { 肝 } \\
\text { 門 }\end{array}$ & 脈 & $\begin{array}{l}\text { 胆 } \\
\text { 管 }\end{array}$ & $\begin{array}{l}\text { 胆 } \\
\text { 童 }\end{array}$ & 䐙 & $\frac{ \pm}{\text { 指 }}$ & 結 & $\begin{array}{l}\text { 後 } \\
\text { 腹 } \\
\text { 膜 }\end{array}$ & 肝 & 肺 & 腎 & 副 & 骨 & $\begin{array}{l}\text { 畉 } \\
\text { 巣 }\end{array}$ & $\begin{array}{l}\text { 腹 } \\
\text { 膜 }\end{array}$ & $\begin{array}{l}\text { 肝 } \\
\text { 門 }\end{array}$ & $\begin{array}{l}\text { 茧 } \\
\text { 周 } \\
\text { 囲 }\end{array}$ & $\begin{array}{l}\text { 腸 } \\
\text { 間 } \\
\text { 膜 }\end{array}$ & $\begin{array}{l}\text { 旁 } \\
\text { 递 } \\
\text { 脈 }\end{array}$ \\
\hline \multirow{2}{*}{$\begin{array}{l}\text { 眀 } \\
\text { 管 } \\
\text { 虚 }\end{array}$} & 切除例 & 4例 & 2 & 2 & & & & & & 1 & 2 & & & & & & 1 & 2 & 2 & 1 & \\
\hline & その他 & 13 & 3 & 7 & & 4 & 2 & 3 & & & 6 & 2 & 1 & 1 & 1 & & 1 & 2 & 2 & 2 & \\
\hline \multirow{2}{*}{$\begin{array}{l}\text { 胆 } \\
\text { 癌 }\end{array}$} & 切除例 & 6 & 4 & 4 & & & & & 1 & 1 & 2 & 2 & & & & & 1 & 2 & 1 & & 1 \\
\hline & その他 & 19 & 5 & 17 & 8 & & 7 & 5 & 3 & & 5 & 7 & 1 & 1 & & 1 & 10 & 5 & 6 & 1 & 7 \\
\hline \multirow{2}{*}{$\begin{array}{l}\text { 䫣 } \\
\text { 涪 }\end{array}$} & 切除例 & 3 & 1 & 2 & & & 1 & & & 1 & & 1 & 1 & & & & & & 2 & & \\
\hline & その他 & 1 & 1 & 1 & 1 & & 1 & 1 & & & 1 & & & & & & & & & & 1 \\
\hline
\end{tabular}

\section{2）胆毫癌剖検例}

胆震癌剖検例は25例で，肝浸潤が21例（84\%）と最 も多く，次いで肝門部浸潤 9 例(36\%)，胆管 8 例，苇 7 例, 十二指腸 5 例, 結腸 3 例となっている。遠隔転 移では肺 9 例 $(36 \%)$ ，肝 7 例 $(28 \%)$ ，その他腎，副 腎, 卵巣各 1 例であった。腹膜播種は11例（44\%）に 認められ，高率であった。リンパ節転移は肝門及び膵 周囲に 7 例 $(28 \%)$ つうつで，腸間膜には 1 例認められ た。特記すべきは旁大動脈に 8 例（32\%）にみられた ことで，転移傾向の大なることが思われる。

切除後再発の剖検例は 6 例あるが，このうち治庱切
除であった 4 例をみると，やはり肝・肝門を中心とし た局所再発が 2 例に認められたが， 2 例は肝転移，肺 転移など遠隔転移のみであった。この 2 例の直接の死 因は消化管出血であった。すすなわち局所は完全に切除 し得ても遠隔転移の傾向の大なることが判る.

\section{3）乳頭部癌剖検例}

4 例中 3 例は膵頭十二指腸切除術後で， 1 例は非志 除例である. 切除 3 例中 1 例はへモクロマトージスに より死亡したが，剖検により癌の再発はみられなかっ た. しかし, Panc ${ }_{1}$ 及び Panc ${ }_{2}$ の例は局所再発があり, 肝・肺転移がみられ，直接の死因は肝膿瘍であった。

表 7 剖検例における癌進展と組織像

\begin{tabular}{|c|c|c|c|c|c|c|c|c|c|c|c|c|c|c|c|c|c|c|c|c|c|}
\hline \multicolumn{22}{|c|}{-46 例一 } \\
\hline & & & \multicolumn{5}{|c|}{ 浸 } & \multicolumn{3}{|l|}{ 潤 } & \multicolumn{4}{|c|}{ 転 } & \multicolumn{3}{|c|}{ 移 } & \multicolumn{4}{|c|}{ リンバ節転移 } \\
\hline & & & $\begin{array}{l}\text { 肝 } \\
\text { 門 }\end{array}$ & 肝 & $\begin{array}{l}\text { 胆 } \\
\text { 管 }\end{array}$ & $\begin{array}{l}\text { 胆 } \\
\text { 垔 }\end{array}$ & 䐙 & $\begin{array}{c} \pm \\
\text { 指 } \\
\text { 腸 }\end{array}$ & 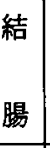 & $\begin{array}{l}\text { 後 } \\
\text { 腹 } \\
\text { 膜 }\end{array}$ & 肝 & 眠 & 腎 & $\begin{array}{c}\text { 副 } \\
\text { 腎 }\end{array}$ & 骨 & $\begin{array}{l}\text { 畉 } \\
\text { 巣 }\end{array}$ & $\begin{array}{c}\text { 腹 } \\
\text { 膜 }\end{array}$ & $\begin{array}{l}\text { 肝 } \\
\text { 門 }\end{array}$ & $\begin{array}{l}\text { 椫 } \\
\text { 周 } \\
\text { 囲 }\end{array}$ & $\begin{array}{l}\text { 腸 } \\
\text { 間 } \\
\text { 膜 }\end{array}$ & $\begin{array}{l}\text { 旁 } \\
\text { 勲 } \\
\text { 脤 }\end{array}$ \\
\hline \multirow{4}{*}{$\begin{array}{l}\text { 胆 } \\
\text { 管 } \\
\text { 㾖 }\end{array}$} & 高分化腺癌 & 13例 & 5 & 7 & & 2 & 1 & 2 & & 1 & 4 & 1 & & & 1 & & 2 & 3 & 3 & & \\
\hline & 中分化腺癌 & 3 & & 1 & & 1 & & & & & 3 & & & & & & & 1 & 1 & 3 & \\
\hline & 低分化腺癌 & 1 & & 1 & & 1 & 1 & 1 & & & 1 & 1 & 1 & 1 & & & & & & & \\
\hline & 計 & 17 & 5 & 9 & & 4 & 2 & 3 & & 1 & 8 & 2 & 1 & 1 & 1 & & 2 & 4 & 4 & 3 & \\
\hline \multirow{5}{*}{$\begin{array}{l}\text { 胆 } \\
\text { 瘄 } \\
\text { 癌 }\end{array}$} & 高分化腺癌 & 13 & 7 & 10 & 3 & & 4 & 1 & 2 & & 4 & 4 & & 1 & & 1 & 6 & 2 & 7 & & 1 \\
\hline & 中分化腺癌 & 3 & 1 & 3 & 1 & & 1 & 2 & & & 2 & 1 & 1 & & & & & & 1 & 1 & 3 \\
\hline & 低分下腺癌 & 7 & 2 & 7 & 3 & & 2 & 2 & 2 & & 3 & 5 & & & & & 5 & 5 & & & 4 \\
\hline & その他 & 2 & & 2 & 1 & & & & & 1 & & & & & & & & & & & \\
\hline & 計 & 25 & & 22 & 8 & & 7 & 5 & 4 & 1 & 9 & 10 & 1 & 1 & & 1 & 11 & 7 & 8 & 1 & 8 \\
\hline \multirow{3}{*}{$\begin{array}{l}\text { 乳 } \\
\text { 鳆 } \\
\text { 澺 }\end{array}$} & 高分化腺癌 & 3 & 1 & 2 & & & 1 & & & 1 & & 1 & 1 & & & & & & 2 & & \\
\hline & 中分化腺潽 & 1 & 1 & 1 & 1 & & 1 & 1 & & & 1 & & & & & & & & & & 1 \\
\hline & 計 & 4 & 2 & 3 & 1 & & 2 & 1 & & 1 & & 1 & 1 & & & & & & 2 & & \\
\hline
\end{tabular}




\section{4)組織像と癌進展}

組織像之癌進展との関係をみると(表 7$)$, 胆管癌で は高分化腺癌が13例，76\%を占め，中・低分化癌は 4 例，24\%と少ない，肝転移をみると高分化腺癌におい ては 4 例，30\%にみられたのに対し，中・低分化腺癌 においては 4 例，100\%に認められた。肺転移において 屯高分化腺澏では 1 例，7\%にすぎないが，中・低分 化腺癌では25\%であった。リンパ節転移に関しても前 者の $23 \%$ に対し，後者は75\%と高率であった。

胆咅癌においては約半数の 13 例， $52 \%$ が高分化腺癌 で，中・低分化腺癌は10例，40\%であった。 その他， 扁平上皮癌及び類腺癌が 1 例つつみられた，高分化腺 癌においては肝転移は 4 例, 30\%,肺転移も4 例, $30 \%$, 腹膜播種は 6 例, $46 \%$ にみられ,リンパ節転移は肝門・ 膵周囲は比較的多いが，旁大動脈には 1 例， $7 \%$ に過 ぎなかった。これに反し，中・低分化腺癌では肝転移 5 例， $50 \%$ ，肺転移 6 例， $60 \%$ ，腹膜播種 5 例， $50 \%$ にみられ，リンパ節転移は特に旁大動脈に 7 例， $70 \%$ と高率であった。

乳頭部癌に関しては高分化腺癌 3 例, 中分化腺癌 1 例で，低分化腺癌はなかった。

\section{考案}

胆道外科の歴史は末た浅く，近年 US 等による診断 あるいはPTC-Dの進歩により急速に発展して来た。 之は云え，その早期診断は尚困難であり，従ってその 切除率は低く，予後は極めて不良である。初期症状は 胆管癌及び乳頭部癌においては黄疸が，胆衰癌におい ては右悸助部痛が多く，この時期に開腹しても既に広 範囲の癌進展あるいは転移があり，姑息的切除あるい は切除不能に終る場合が少くない，胆道癌の中でも， 胆管癌, 胆敩癌及び乳頭部癌はそれぞれ病態が異なり 進展にもかなりの相違がある。こうしたことの検討は 今後の胆道外科にとって必要欠くべからざるものと考 え, 手術例及び剖検例について胆道癌取扱い規䄪 ${ }^{11} に$ 則り検討を加えた。

胆管癌についてみると，手術例については他臟器へ の進展は比較的少いと云うすのの ${ }^{2)}, \mathrm{S}, \operatorname{Hinf}$ が比較的 多くみられ ${ }^{3) ~ 5)}$ これらが Stage 決定に大きな因子(約 50\%)であることを強調している。 また N 因子に関し

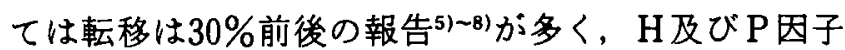
は12〜17\%と比較的少い9，われわれの症例では S 因 子 $90 \%$, Hinf $59 \%$, H $4 \%$ ，P 13\%で，前 2 者は多 いが後 2 者は比較的少い.N因子では組織学的に確認 し得たのは切除例で $42 \% て ゙ ，$ 他の報告よりやや多かっ
た。剖検例ではやはり Hinf が半数以上に認められた が，D及びPancは軽度であった。リンパ節転移は肝 門，苹周囲に認められたが旁大動脈にみられなかった ことは注目すべきである。しかしHが17例中 8 例にみ られたことは注意すべきである。

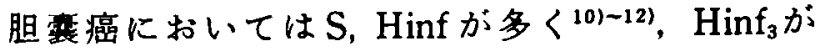
$82 \%$ といら報告むある ${ }^{13)}$ ．われわれの症例では $\mathrm{Hinf}_{2 \sim 3}$ は $52 \%$ に認められ，切除不能の理由として大き な要因となった．しかし，非切除の理由として $B_{3}$ をあ げている報告むある(14)．N因子に関しては持永 ${ }^{12)}$ は切 除44例中24例，54.5\%に転移がみられたとしており， 田代ら”は切除38例中 21 例，55.3\%に転移がみられた という. そしてその中では12b が最も多く21例中12例， $52.1 \%$ ，次いで 8 のリンパ節が 21 例中 10 例， $42.6 \%$ にみられたとしている。われわれの手術例では肉眼的 には75\%に転移陽性と診断したが，組織学的に確認し 得たのは $61 \%$ \%っったＨに関しては手術例において は比較的少なく ${ }^{121}$ ，われわれむ10\%であった，Pに関し ては少いとの報告13)ああるが，われわれは27\%に認め ている.非治疮切除或は非切除となった理由はHinf, Pなどが大きな因子であった。剖検例においてはやは り Hinf が多く, D, Panc も少なくない。転移ではPが 多く，また肺に多いのも注目に値する，Nでは肝門， 椫周囲に多いが，旁大動脈にかなり多いのが治療上問 題になるものと思われる。

乳頭部癌に関しては一般に進展が少く，予後は比較 的良好と云われているが15)，Pancのあるものは不良 で16)，われわれの症例も術後 1 年前後で癌死した。

切除後再発例についてみると, 胆管癌においては肝 門部を中心とする局所再発が認められ，治瘾切除と考 えられた 2 例にも同様な所見が認められた。より広範 囲切除による治瘾切除が望まれる。胆售癌においては やはり肝門部中心の局所再発があり，広範囲の合併切 除が望まれるが，肺転移や遠隔リンバ節転移の傾向が 強く，切除の限界も考えられる。

組織学的にみると，殆んど腺癌であるが, Bockus ${ }^{17)}$ によると，胆管癌では424例中 7 例， $1.6 \%$ に扁平上皮 癌が，主た胆震癌においては未分化癌 $4.6 \%$, 扁平上皮 癌 $4.4 \%$ ，類腺癌 $1.6 \%$ と報告されている。われわれの 症例では胆震癌に执いて扁平上皮癌及び類腺癌がそれ ぞれ1例づつみられた以外，すべて腺癌であった，腺 癌を一応高分化，中分化，低分化に分けてみると，剖 検例においては高分化腺癌が66\%を占め，中分化，低 分化腺癌は少い，特に胆管癌においては高分化 $76 \%$, 
中・低分化腺癌 $24 \%$ となっている。しかし，胆釷癌に おいては高分化腺癌は $52 \%$ とや減少し，逆に低分化 腺癌は $28 \%$ と増加している。組織像と癌進展の関係を 見ると，胆管癌に拈いて Hは高文化腺癌では $30 \%$ に

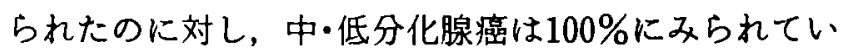
る. 胆震癌に打いても高分化腺癌では $\mathrm{H} 30 \%$, 肺転移 $30 \%, P 46 \%$, 旁大動脈リンバ節転移 8 \%であるに反 ᄂ, 低分化腺癌ではH $42 \%$, 肺転移 $71 \%, \mathrm{P} 71 \%$, 旁大動脈リンバ節転移 $57 \%$ と高率である。組織像と予 後との関係について Tompkins ら ${ }^{18)}$ は胆管癌を乳頭 状腺癌, 高分化腺癌, 低分化腺癌の 3 型に分けると, その 5 生率は乳頭状腺癌の $31 \%$ に対し, 高分化腺癌は $8 \%$ に過ぎないと述べている。われわれの症例におい て胆衰癌に高度進展例が多いのは胆衰癌が低分化の傾 向が強いことと一致するものと思われる。

\section{結 論}

われわれは胆道癌68例（胆管癌29例, 胆震癌35例, 乳頭部癌 4 例）を経験し, 切除22例, 剖検46例を中心 に癌の進展を検討し，次の結果を得た。

胆道癌の進展は主として肝・肝門に向い，この為切 除不能となることが多い，特に胆変癌においては腹膜 播種や肺転移が多く，また产大動脈リンハ節転移に向 ら傾向が強い。このことは胆釷癌においては組織学的 に低分化の傾向にあることと一致する，従って胆衰癌 に関しては早期発見, 早期手術の必要性が痛感される。 胆管癌においては胆衰癌に較べ進展はやや遅い傾向に あり, 拻大手術に上り病巣が完全に切除出来ればその 予後は比較的期待出来るものと考光られる.

稿を終るにあたり，御援助いたたいた川崎市立川崎病院 中央検査科部長福田純也博士に深甚の謝意を表します。本 論文の要旨は第12回日本胆道外科研究会において発表し た.

\section{文献}

1）日本胆道外科研究会編：胆道癌取扱い規約．金原 出版, 1981.

2）田本杲司, 蜂須賀喜多男, 森 直和他：胆道癌の検 討, 外科, $34: 65-73,1972$.

3）江上 格, 渡辺 章, 矢野正和他: 胆管癌の臨床像 と進展様式，日消外会誌，17：140，1984。
4）平田善久，营野千治，岡田佰良他：胆管癌切除例火 おける浆膜漫洞增殖様式(INF)の予後に及注す影 留について，日消外会誌，17：141，1984。

5）川口英弘, 吉田全介，村山裕一他：胆管癌手術例に 捕ける進展様式と予後, 日消外会誌，17：141, 1984.

6）江口礼紀, 羽生富士夫, 中村光司他：切除例からみ た胆管癌の進展様式と予後, 日消外会誌, $17 ： 142$, 1984.

7) 田代征記, 持永瑞恵, 平岡武久他：胆道癌のリン八 節転移について, 胆と羘, $2: 849-856,1981$.

8）鴆田 紘, 中川原儀三, 鬼頭文彦他：胆管癌の進展 様式一特に胆管浸潤とリンバ節転移について，日 消外会誌，17：143，1984。

9）大西英片，金井歳雄，近藤 喬他：切除例，姑息手 術例，剖検例上り之た胆管癌の進展形式，日消外会 誌, $17 ： 142,1984$.

10）諸角強英, 戸泉 篤, 高橋 伸他：胆重癌36例の検 討，日消外会誌，15：127，1982.

11）佐藤光史, 大宮東生, 吉田宗紀他：胆衰癌症例の進 展に関する臨床的, 病理学的検討, 日消外会誌， $15: 128,1982$.

12）持永瑞恵：胆荎癌の進展様式と治療方針に関する 研究，日消外会誌，16:1334-1344，1983.

13）山内昌一郎, 古賀明俊, 住吉金次郎他：胆爱癌49例 の検討, 特に進展形式を中心として, 日消外会誌, $17: 145,1984$.

14）友利千之，伊藤伸一，矢島克昭他：胆震癌の進展形 式，日消外会誌，17：147，1984。

15）中山和道, 佐田正之, 岡部正之：乳頭部癌の臨床病 理学的検討, 胆と膦, $2: 821-828,1981$.

16）松本文夫，小林 滋，桜井秀樹他：乳頭部癌の蕠漫 潤とその術前診断について, 日消外会誌，17：147, 1984 .

17) Bockus, H.L.: Gastroenterology, Volume III. W.B. Saunders Company, Philadelphia, 1974.

18) Tompkins, R.K., Thomas, D., Wile, A., et al.: Prognostic factors in bile duct carcinoma, Analysis of 96 cases. Ann. Surg., 194 : 447-457, 1981. 